\title{
DIAGNOSIS PROCESSES FOR DESERT ROSE DOMES OF THE SOUF REGION IN ALGERIA
}

\author{
C. Azil ${ }^{1,2, *}$, B. Djebri ${ }^{1}$, L. Rovero ${ }^{2}$, \\ 1 LVAP, Laboratoire "Ville, architecture et patrimoine", "Ecole polytechnique d'architecture et d'urbanisme \\ d'Alger EPAU", Algeria - c.azil@epau-alger.edu.dz \\ ${ }^{2}$ Department of Architecture, Materials and Structures Division, University of Florence, Italy
}

KEY WORDS: Souf region, Desert Rose stone, dome, damage, diagnosis, FEM analysis

\begin{abstract}
:
In the Souf region of Algeria, all vernacular buildings are covered by domes, built with an unusual building material, the desert rose stone, peculiar to the region. These domes represent an element of identity of the region and describe a unique urban landscape that deserves to be protected and enhanced. Unfortunately, these architectural elements have suffered damage that devalues the urban landscape compromising their conservation. In particular, many domes have severe cracks and have collapsed in large areas.

Diagnostic investigations were carried out with the aim to understand the causes of the damages and to carry out guidelines for consolidation.

In particular, in situ surveys have allowed to analyze the employed construction technique, the collection of samples for the chemical-physical and mechanical investigations of the materials and a manual geometric survey of a typical building module. In addition, a Finite Element Model of a building module was realized with the aim of investigating structural behavior.

Considerations were made on the influence of the dome shape on structural behaviour and on the fractures pattern detected in many domes
\end{abstract}

\section{INTRODUCTION}

In the Souf region of Algeria, surrounded by the desert, some oasis preserves a Cultural Heritage of great value that must be protected and handed down to future generations. In fact, in this region almost all buildings are covered by domes and consequently the amazing urban landscape is strongly characterized, showing uniqueness, constructive peculiarity and harmony with the environment. For these reasons, the Souf Oasis is mentioned in the "Tentative List of UNESCO".

The use of the domes has appeared since the founding of three historic cores in this region namely Guemar, Z'goum and Oued towards the end of the sixteenth century (Coté, 2006), becoming an identity element of the culture of the Souf region. The domes are built with an unusual building material: the desert rose stone. This local material played the large role for this particular vernacular architecture and specifically for the construction of the domes.

Unfortunately, many domes have damage states, from superficial erosions to partial or total collapses. These damages devalue the urban landscape of the Souf region and it is urgent to develop strategies for protection and enhancement. With this aim, it is important to develop diagnosis process that can find the sources of pathologies, to find solutions, and to propose guideline to rehabilitation operations, effective and compatible with the delicate and peculiar constructive context (Boostani et al, 2018) (Jorquera et al, 2017) (Baglioni et al, 2016) (Baglioni et al, 2016)( Liberotti et al, 2016)( Rovero et al ,2013)( Gamrani et al ,2012)( Rovero et al ,2012) ( Sani, 1999) .

\section{THE CONSTRUCTIVE TECHNIQUES}

In agreement with (Coté, 2006), the amazing, peculiar and unique landscape of the Souf region does not count only in the movement of erg dunes, but also in unexpected human creation. In fact, using local materials, the ancient builders invented a building technique and an urban architecture of great interest, where the dome is the protagonist (Figure.1).

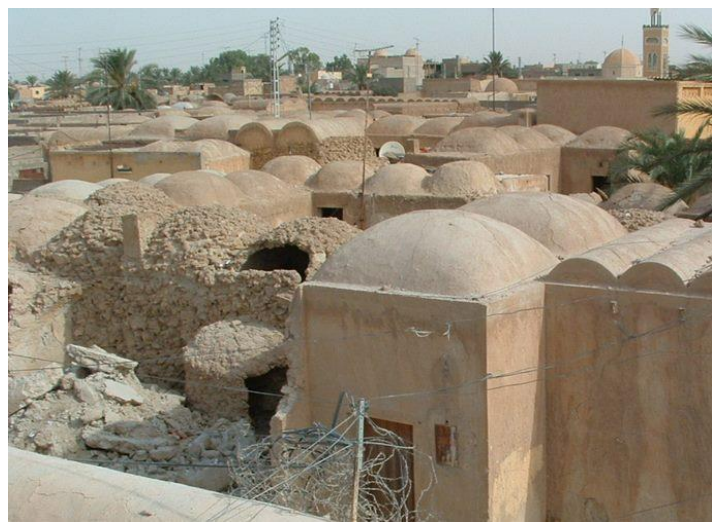

Figure 1. Old center of Guemar, Souf.

In-depth in-situ surveys have allowed to detect and study the employed construction technique, also taking samples for a mechanical investigation.

The buildings of the historical centers of the Souf region are entirely made of Desert Rose stone blocks of very irregular shape and size. The Desert Rose stone is an unusual build material, made of gypsum crystals, nested and spearhead shaped

\footnotetext{
* Corresponding author
} 
with length up to 20 to $30 \mathrm{~cm}$ long. The joint mortar, used in abundant quantities due to the irregularity of the blocks, is realized using as binder the Tafza, white sandstone composed of gypsum. The Tafza is also the raw material for the plaster mortar (Mangin et al, 1987) (Bataillon, 1955). It is interesting to note that both the blocks and the mortar for the masonry construction have a similar composition based on the gypsum minerals. This circumstance should confer a good adhesion between blocks and mortar determining a good mechanical behaviour of the walls and domes.

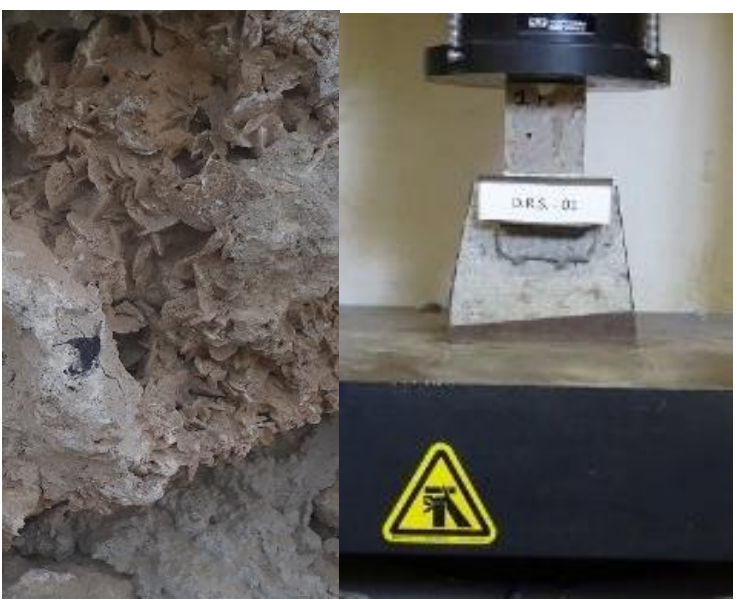

Figure 2.(a) The Desert Rose stone. (b) Compression test on Desert Rose stone sample.

Compression test on Desert Rose stone samples allowed to determine $10 \mathrm{MPa}$ for the compressive strength and $1350 \mathrm{MPa}$ for the Young modulus.

The experimental analysis highlights that the block material is characterized by rather low mechanical characteristics with very dispersed experimental values. These results depend on the very heterogeneous nature of the material which also has a high porosity. The texture of the masonry is very chaotic, being the employed desert rose blocks very irregular. In fact, the blocks are not squared and different sizes of the blocks are used. In figure 3, the really chaotic texture of the walls is represented. For these reasons it is easy to assume that the mechanical characteristics (compressive strength and elastic modulus) of the masonry (blocks and mortar) are much reduced compared to those of the blocks.

The buildings are organized around a courtyard and are made up of a sequences of basic square unit of $2.5 \mathrm{~m}$ side. Above each unit, a dome is built, quite lowered with very little diagonal edges.

The walls are usually $0.30 \mathrm{~m}$ thick, and the domes are about $0.20 \mathrm{~m}$ thick (Figure 3 ). The dome is set at a height between 2 to $2.5 \mathrm{~m}$.

The construction of the dome is done without formwork, thanks to the use of gypsum-based mortars that quickly set. The execution starts from the square base and grows progressively on the same level carrying out in the corners small mortar squinch. Using the Desert Rose stone blocks and gypsum based mortar, without the use of the formwork, the mason rises the successive courses, one above the other, until the center. The shape of these domes is close to a cloister dome, but the discontinuities in the edges along the diagonal arches is very smooth. Both the walls and the domes are then coated with plaster ( Azil et al, 2017)

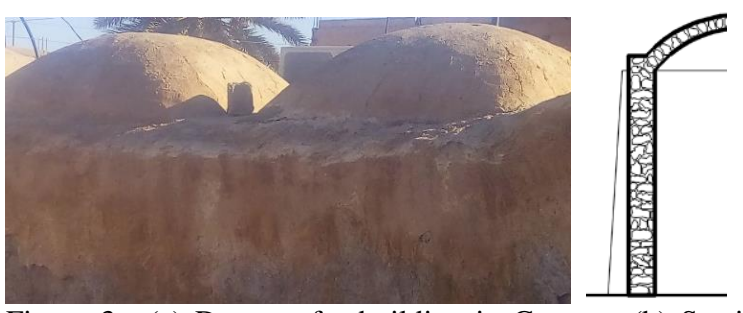

Figure 3. (a) Domes of a building in Guemar. (b) Section of wall and dome.

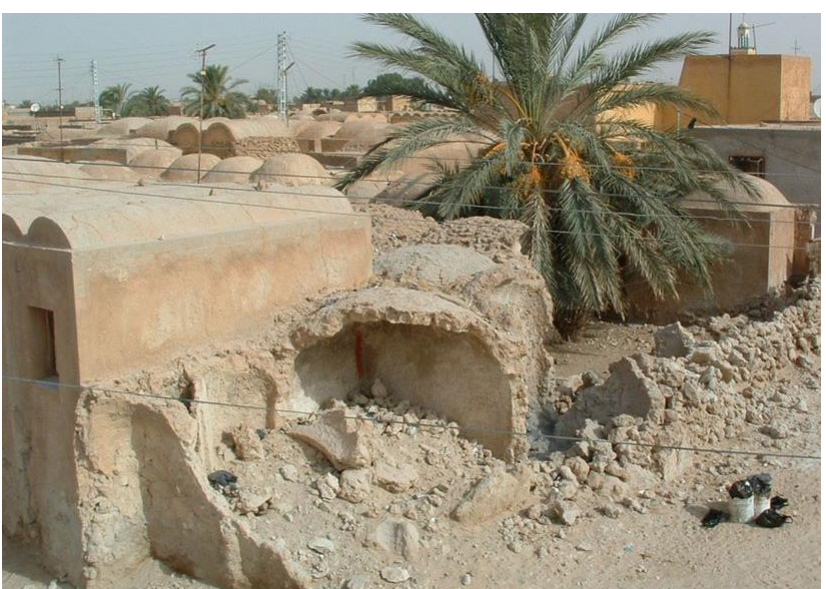

Figure 4. The degradation states of building in the Guemar.

\section{ANALYSIS OF THE DEGRADATION STATE}

Currently, the degradation state of the architectural heritage of Souf region are very remarkable. Such degradation states are widespread and is characterized by different levels of gravity. In some cases, surface erosion states of the plaster have been highlighted. This degradation often goes up to the complete detachment of parts of the plaster of the domes, leaving the masonry exposed to atmospheric agents (Figure 5). It is important to underline that in this region the action of the wind is very strong and therefore the erosive phenomena are emphasized.

In many cases serious structural damages are evident. In particular, in many buildings partial or total collapse of the domes happened. In many other buildings, it is possible to detect serious cracks that involve the domes (Figures 6 and 7). In particular, there are large fractures at the corners of the domes (along the diagonal arches), determining fragmentation of the domes (Figure 6). These fractures allow the dangerous passage of water and the degrading action of atmospheric agents and can lead the domes to collapse if not repaired.
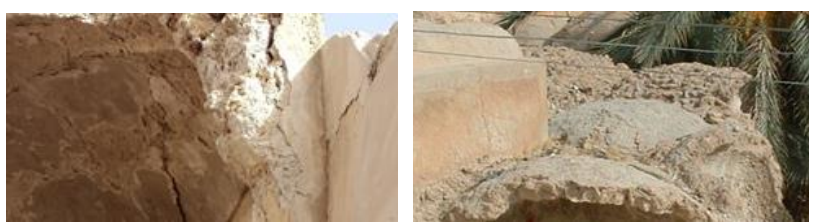

Figure 5. Crumbling of the surface layers of plaster. 


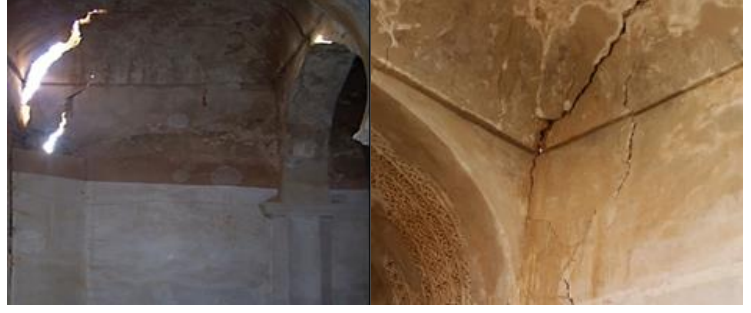

Figure 6. Fractures at the corners of the domes, along the diagonal arches.
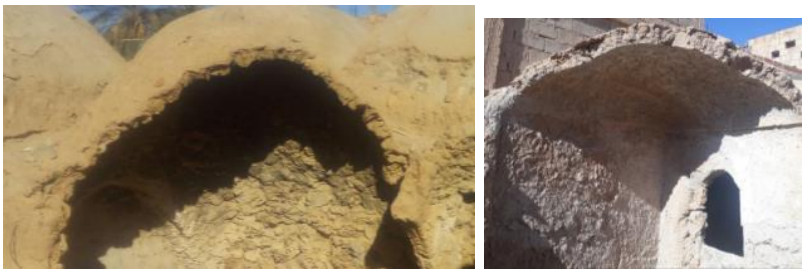

Figure 7. Partial collapse of the domes.

\section{STRUCTURAL BEHAVIOR}

It is known that the causes of degradation states could have endogenous origins, i.e. related to the construction itself, or exogenous origins, i.e. caused by external factors. As concern the endogenous degradation factors, the structural behavior of the domes was investigated in order to highlight the inherent weaknesses.

In agreement with ( Borri et al,2011) the structural behaviour of the cloister dome can be explained considering the dome consisting of two diagonal arches that transfer the vertical weights, but not the horizontal trust, at the corners of the building unit and a series of flying buttresses arches that discharge the vertical weight and the horizontal thrust along the load-bearing walls (Figure 9).

At the diagonal arches, there is a geometric-constructive discontinuity which determines structural weaknesses. Further weakness is generated in the middle of the building unit sides where the horizontal thrust of the flying buttresses arches is maximum. Such thrusts can cause the overturning of the top part of the walls and the partial collapse of the dome (Figure 6).

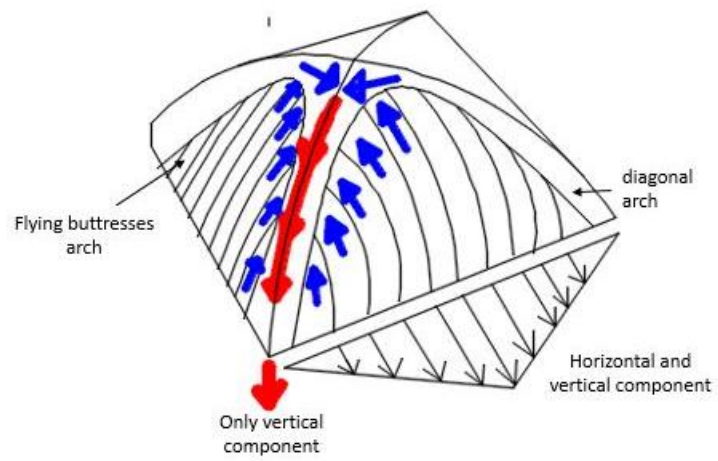

Figure 8 . The structural behavior of the cloister domes. Elaboration from (Borri et al, 2011)

\subsection{FEM analysis of the dome}

The "Straus7" software was employed in order to carry out a numerical analysis by means of the finite element method (FEM) of a typical dome of Souf region. This software permits performing linear elastic analyses using plate/shell finite elements, characterized by both membrane and bending behaviour.

The elements (called Quad4) are characterized by four nodes with six degrees of freedom for each node. Each element is characterized by a thickness that takes into account the real thickness of the dome, which varies with the height. The nodes at the springing of the dome were restrained with hinges. For the elastic modulus, experimental results on samples of desert rose were employed.
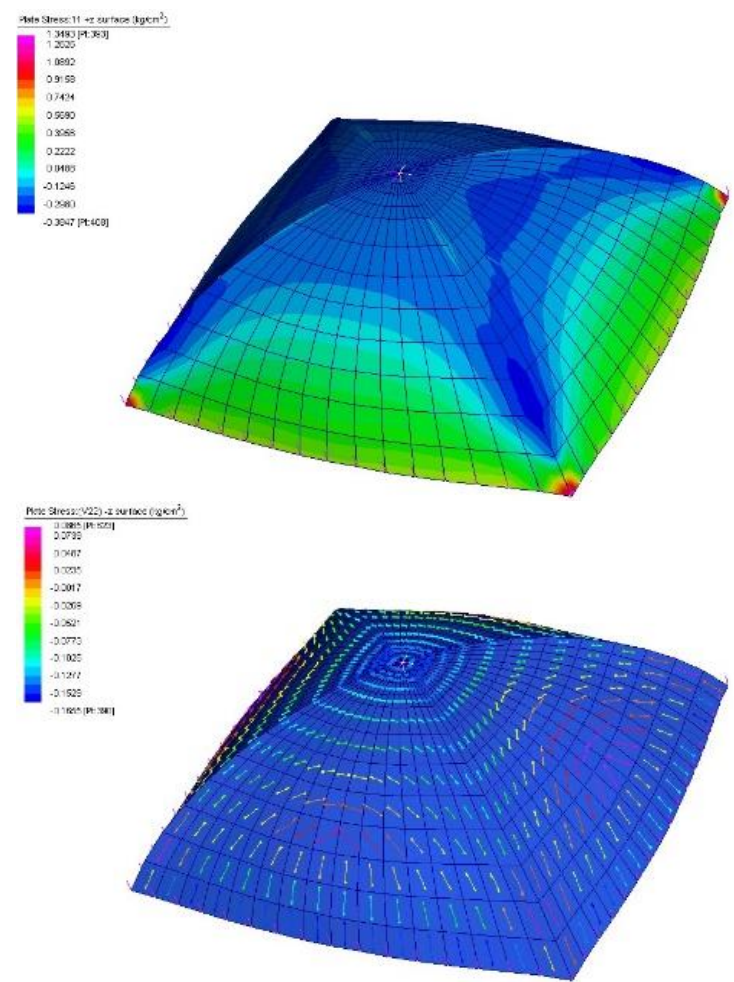

Figure 9. FEM analysis: stress 22 in extrados and stress 11 in intrados

The results of FEM analysis confirm the typical structural behavior of the pavilion vaults: diagonal arches and flying buttress arches.

The compression stress is variant along diagonal arches and shows a progressive increase from the key to the abutament. The maximum values of the compressive stresses at the diagonal arcs are $0.1 \mathrm{MPa}$, values absolutely compatible with the compressive strength of the material.

The maximum tensile stress value, $0.05 \mathrm{MPa}$, are present on the sides of the diagonal arches at the abutments. These values are high for the characteristics of the material and justify the triggering of visible lesions in the studied domes. 


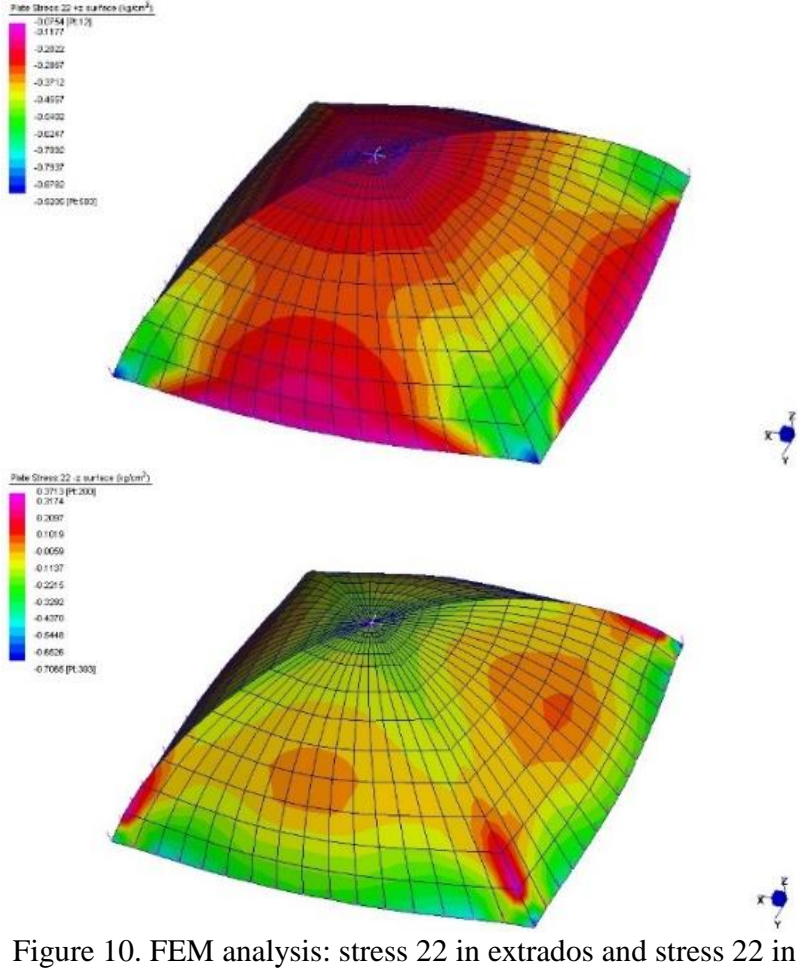
intrados

\section{CONCLUSION}

A multi-scale investigation was carried out on an original architectural heritage present in the Seuf region in Algeria. This heritage consists of vernacular architectures built with desert rose stone blocks and characterized by dome roofs, which describe a unique urban landscape. Unfortunately, many domes have severe cracks and collapses in large zone, devaluating this architectural heritage.

In order to preserve the architectural heritage of the Souf region, a diagnostic process was carried out. In particular, the following investigations were performed:

- Study of the used construction technique.

- Experimental tests on materials samples.

- Manual geometric survey of a base cell constituting the buildings.

- Analysis of degradation states- FEM analysis of a typical dome.

The obtained results have allowed to understand some of the causes of the widespread damage in the domes.

Because of its shape, the cloister dome has weakness zones where fractures can occur. These zones are at the abutments of the diagonal arches. In addition, the cloister dome generates pushes at the mid-points of the underlying walls. These structural weaknesses are amplified in the case of the domes of the Souf region because the shape is very low and the material has low mechanical characteristics.

\section{REFERENCES}

Azil, C., Djebri, B., Rovero, L. 2017. Desert rose: building material of cupolas in the Souf in Algeria. In : Sustainable
Buildings and Cities 2017 on IOP Conf. Series: Materials Science and Engineering 567, IOP Publishing, Fez .

Baglioni, E., Fratini, F., Rovero, L., 2016. The characteristics of the earthen materials of the Drâa valley's architecture. Journal of materials \& environmental science, 7, 3538-3547.

Baglioni, E., Rovero, L., Tonietti, U., 2016. Drâa valley earthen architecture: construction techniques, pathology and intervention criteria. Journal of materials \& environmental science, 7, 3499-3508.

Bataillon, C. 1955. Le Souf. Étude de géographie humaine. Université d'Alger, Alger.

Boostani, A.,Fratini, F., Misseri, G., Rovero, L., Tonietti, U., 2018. A masterpiece of early Islamic architecture: The NohGonbad Mosque in Balkh, Afghanistan. Journal of cultural heritage, 32 , 248-256.

Borri, A., Bussi, L. 2011. Archi e volte in zona sismica. Meccanica delle strutture voltate, Doppiavoce, Napoli.

Coté, M., 2006. Si le Souf m'était conté. Comment se fait et se défait un paysage. Média-Plus, Constantine .

Gamrani, N., Chaham, K. R., Ibnoussina, M., Fratini, F., Rovero, L., Tonietti, U., Mansori, M., Daoudi, L., Favotto, C., Youbi, N. 2012. The particular "rammed earth" of the Saadian sugar refineryof Chichaoua (XVIth century, Morocco): mineralogical,chemical and mechanical characteristics. Environmental earth sciences, 66(1), 129140 .

Jorquera, N., Misseri, G., Palazzi, N. C., Rovero, L., Tonietti, U., 2017. Structural characterization and seismic performance of San Francisco church, the most ancient monument in Santiago, Chile. International journal of architectural heritage, 11, 1061-1085.

Liberotti, G., Rovero, L., Stipo, G., Tonietti, U., 2016., Mechanical investigation on adobe samples belonging to the archaeological site of Arslantepe (Malatya, Turkey). Journal of materials \& environmental science, 7, 3656-3666.

Mangin, D., Panerai, P. 1978, Institutions et formes urbaines. Guémar et Tamelhat, Algérie, Architecture Mouvement et Continuité, 48 ,63-73.

Rovero, L .,Fratini, F., 2013: The Medina of Chefchaouen (Morocco): A survey on morphological and mechanical features of the masonries. Construction and building materials, $47,465-479$.

Rovero, L., Tonietti, U., 2012. Structural behaviour of earthen-corbelled domes in the Aleppo's region. Materials and structures, $45,171-184$.

Sani, F., Moratti, G., Coli, M., Laureano, P., Rovero, L., Tonietti, U., Coli, N .2012. Integrated geologicalarchitectural pilot study of the Biet Gabriel-Rufael rock 
The International Archives of the Photogrammetry, Remote Sensing and Spatial Information Sciences, Volume XLII-2/W11, 2019 GEORES 2019 - 2nd International Conference of Geomatics and Restoration, 8-10 May 2019, Milan, Italy

hewn church in Lalibela, northern Ethiopia. Italian journal of geosciences, 131 (2), 171-186. 